\title{
Demonetisation in India: An Impact Assessment
}

\author{
Ashwani' and Geethanjali Nataraj2* \\ 'Assistant Professor, NIT, Kurukshetra, Thanesar - 136119, Haryana, India; ashwani.mbe@gmail.com \\ 2Professor, IIPA, New Delhi - 110002, Delhi, India; geethanjali_n@yahoo.com
}

\begin{abstract}
Indian economy took a historic move of banning high denomination notes measured as 87 percent of total currency in November 2016. The early objectives of the move were linked to various issues such as curbing black money, removing counterfeit currency and stopping terrorist funding. But in due course the implications of demonetisation have been pronounced in the form of wider tax base through accounted income, progress towards a cashless economy, increase in bank deposit balances under Basel III accord, controlling inflationary activities, removing the asset bubbles through limited cash availability, etc. In this regard, several academics have carried out their own analysis of demonetisation and its effects but most of the research work has addressed the partial effects of the demonetisation move and have been carried out in the early months of the move. But now that the economy has crossed about one and a half year of this landmark reform, there is ample scope to measure the true impact of demonetisation on the financial system, inflation and real economy of India. The paper concludes that overall the effects of demonetisation on the economy can be said to be neutral. Interestingly, macro indicators of the economy have improved in recent years despite two major initiatives of demonetisation and GST reforms. This reflects that the resistance of the Indian economy continues due to its strong demand. This is of prime importance for reviving investment in the economy, which in turn, has wider implications for the overall growth and development.
\end{abstract}

Keywords: Demonetisation, Digitalisation, Fiscal Health, Financial Sector, Real Economy

JEL classification: E23, E31, E44, E51, E66

\section{Introduction}

The formal announcement of demonetisation of high currency denomination notes of Rs. 500 and Rs. 1000 worth nearly 15.4 trillion, took place on November 8 , 2016. The Indian move has been unlike the experiences of Canada and Singapore, where printing of high value notes was discontinued; and existing notes were called back, through banks without calling them illegal tender ${ }^{1}$. The move in India aimed at curbing corruption, black money, eliminating counterfeit currency and terrorism funding. Alongside, it aimed at the promotion of a cashless economy mainly through digitisation, converting the informal economy to a formal one, increasing the scope for financial inclusion, enhancement of financial savings, and larger scope for strengthening of treasury accounts of the Government, ultimately to be utilised for financing development. It was also anticipated that demonetisation may result in other positive developments such as adoption of faster technology, increase in tax base ${ }^{\mathrm{a}}$, and possibility of lower tax rates ${ }^{2}$.

Economic rationale behind the move is generally attributed to three factors - controlling hyperinflation, removing counterfeit currency, and widening the tax base. It was also expected that demonetisation would help in reducing interest rates in the banking system amid the flush of huge funds and possibility of pass-on effect of fall in interest rates to the investment in the country ${ }^{2}$. It was believed that demonetisation would foster the use of bank accounts and digital payments, making the Indian economy less cash-dependent and improve efficiency and productivity ${ }^{\mathrm{b}}$.

However, given the low inflation rate and small proportion of black money existing as cash in the

${ }^{*}$ Author for correspondence 
economy, critical analyses of the reform measure question the economic rationality behind it ${ }^{3}$. The major chunk of black money was invested in business, stocks, real estate, jewellery, or "benami" assets - assets which were bought in someone else's name. India depends primarily on cash based transactions and only 10-15 percent of the population are non-cash users compared to 40 percent in countries like Brazil and China. Also, the ratio of currency in circulation outside of banks to GDP is 11.1 percent, higher than the other emerging economies like Russia, Mexico, and Brazil ${ }^{4}$. Even online shopping in India is done with cash, about 70 percent of online commerce is paid with cash on delivery ${ }^{c}$.

Recent literature has looked at various dimensions of the demonetisation move. The right wing calls the move a great success in terms of promotion to a cashless economy, rise in number of tax payers, curtailing counterfeit currency, controlling inflation, etc. The positive thinkers expected for advantages of the move in terms of tax collection amount, revival in investment under surplus liquidity, fulfilling the capital requirements of banks under Basel III, and balance to bubbles in asset prices. After examining statistics related to income tax, it was concluded that the number of persons filing income tax returns as well as income tax ${ }^{\mathrm{d}}$ has increased substantially. Moreover, about 1.8 million bank accounts with the unusual' cash deposits of approximately Rs 1.7 lakh crores during demonetisation period are under the lens of the Government. The demonetisation move might have added an extra burden ${ }^{\mathrm{e}}$ on RBI; however, the cost of shortfall of capital in the Indian banking industry under the international accord of Basel III is of utmost importance, which can be managed by maintaining surplus balance with the central bank. The asset side of RBI has risen on the ground of increase in foreign investments and domestic investments by 2.7 percent and 7.45 percent respectively. However, the potential impact on investment revival in coming years through increased credit is yet to be confirmed. Also, the surmountable printed cash to GDP ratio ${ }^{\mathrm{f}}$ has been a major challenge for Indian economy to safeguard itself from the asset bubbles, similar to what had happened in the U. S. during 2004-08 amid reckless lending. In fact, some academicians ${ }^{5}$ have argued that demonetisation acted as a safeguard for the India economy against the excessive flow of cash into the economy which rendered the hike in asset prices well above their real behaviourg.
Statistics released by RBI in the month of June 2017 have cast doubt about the "curbing black money" aim of the demonetisation move. As per its report, 99 percent of the declared illegal tenders returned to the Central Bank, with merely 1 percent amounting to Rs. 16,050 crores not coming back. The former RBI Governor mentioned that short-term economic costs of demonetisation would outweigh the long-term benefits of the move. Demonetisation led to an extra burden of Rs. 7,965 crores on RBI spent on printing of new notes. Further, the liabilities of the RBI also increased in terms of the interest on reverse repo deposits of banks lying with the Central bank. Also, the fall in economic growth in the first quarter of FY 2017-18 to 5.7 percent, against 7.9 percent the previous year is attributed to the slowdown in the economy amid the demonetisation move. However, the lower growth due to demonetisation move cannot be netted out completely, as another major reform- GST was announced where firms were doubtful about the settlements of stocks. Given that the Indian economy experienced demonetisation about 18 months ago, it is important to analyse and assess its impact and consider if there is evidence supporting previous arguments laid down by different academicians. The rest of the paper is organised as follows. Section 2 presents the review of literature with focus on the impact assessment of demonetisation. Section 3 brings out the empirical analysis for impact assessment of the move on Indian economy including impact on the financial sector, rural economy, and digital economy and the final section presents conclusion.

\section{Impact Assessment: Overview of Literature}

The theoretical relation between money supply and economic output dates back to quantity theory of money where fall in money supply could be equalised to decrease in output amidst fixed velocity ${ }^{\mathrm{h}}$. It was reported that the share of 'currency with the public' in the total money supply reduced significantly and deposits grew up to new highs. Bank credit to the commercial sector has seen a decline post demonetisation ${ }^{6}$. The amount of currency in circulation edged higher in January 2017 although it remained 45 percent below its October 2016 level $^{\mathrm{T}}$. During demonetisation, the impact on Gross value added was felt mostly in real estate and construction, 
but was somehow offset by parallel rise in agriculture, manufacturing, electricity and mining. As per the CMIE estimates the new investment proposals dropped to 1.41 trillion in Q3 of 2016-17 as against an average of 2.36 trillion in the preceding nine quarters. Food inflation has eased from 3.7 percent year-on-year (y-o-y) in October 2016 to 1.3 percent in January 2017 mainly on account of plunge in vegetables and pulses prices. Manufacturing and services segments were hit hard amid the move as the auto sales contracted by 4.7 percent in January 2017 but returned to expansion mode (by 0.9 percent) in February. Cement production has declined continuously from November 2016 till January 2017. Sales of commercial vehicles also experienced the same phenomenon but revived in February by 7.3 percent. Passenger vehicles noticed a fall of around 2 percent in the beginning period of demonetisation but rebounded sharply to 14.4 percent in January 2017 and expanded by 9 percent in February. In a recent study, it was added that real GDP growth in India slowed modestly from 7.3 percent in Q3 of 2016 to 7.0 percent in Q4, which was not as sharp a fall as many analysts had expected ${ }^{15}$. Chand and Singh assessed the impact of demonetisation on Indian agriculture and argued that growth story of agriculture is intact ${ }^{\stackrel{8}{ }}$.

Regarding the banking sector, a fall in interest rates has been witnessed due to increased funds supply post demonetisation. Insurance sector has also gained as the premiums collected by life insurance companies more than doubled in November 2016 and LIC largely enjoyed the upsurge $e^{i}$. The impact towards financial inclusion was evident as 23.3 million new accounts were opened under the Pradhan Mantri Jan Dhan Yojana (PMJDY) and the total balance reached to Rs. 746 billion as on December 7 , 2016 reporting a growth of around 65 percent. The impact of demonetisation on various segments of the financial market has varied. However, demonetisation's impact on stock market, exchange rate and Government Securities market cannot be netted out as the new leadership in the U.S. had earmarked agendas of more protectionist trade policies, tightening of U.S. monetary policy, and possibly expansionary fiscal policy. There has been a significant improvement in the use of digital modes of payments 9 . Similar types of impact on real sectors, banking sector in terms of credit expansion and interest rates, government securities' market and availability of cash into the system was also highlighted by CARE rating $s^{10}$.

CARE Ratings ${ }^{j}$ had estimated that demonetisation would have adverse impact on growth due to deferred manufacturing demand and irrevocable service sector. Few case studies like Jean Drèze reports a 45 percent decline in earnings of small shopkeepers/businesses in Ranchi ${ }^{11}$; Prateek Sibbal points out 46 percent decline in Amritsar ${ }^{12}$; Vyom Anil indicates a 60 percent fall in Delhi ${ }^{13}$; among others. The employment scenario mainly contributed by informal sector has noticed a sharp fall. As per the report of Ministry of Rural Development, the demand for MNREGA (Mahatma Gandhi National Rural Employment Guarantee Act) work increased by 60 percent in December 2016 confirming the jobless environment ${ }^{14}$. RBI has argued that the transient impact was observed in the beginning of the demonetisation move but the economy could sustain the earlier level by mid-February of 2017, reflecting the fast pace of remonetisation². Bryson et al. ${ }^{7}$ mentioned that the transient negative effects of demonetisation would eventually dissipate; however, the economic reform process is the key to sustain longrun growth. Most of the studies have captured the time period of the study from November, 2016 onwards to March 2017. However, in the present study, the previous two years (2014 and 2015) and most recent time period till Q3 of 2017-18 (post one and half years of the move) is covered to draw a fruitful impact assessment of the demonetisation move in India.

\section{Macroeconomic Impact of Demonetisation}

\subsection{Demonetisation and Indian Financial Sector}

As per the monetarist view, the effect of demonetisation on economic activities and stock market is related to the fall in interest rates. However, the real side impact of any demonetisation move will also depend upon the relative share of connected and unconnected sectors of the economy ${ }^{15}$. Demonetisation has led to increase of cash flows in the banking system. An event study utilized the daily data of BSE 200 stock index and revealed a 9 percent reduction in the shareholders' wealth during eight trading days immediately after the announcement of demonetisation. The market perceived the move negatively ${ }^{16}$. The short-run impact of demonetisation on creating volatile markets is intuitive. However, the longrun impacts are well aligned to economic theories. 
Figures 1 and 2 present the behaviour of interest rates, credit extended, deposit received and investment utilised for the period 2012-18. The growth rate in deposit has been around 14 percent during 2012-13 (measured on left axis of Figure 1), but the same came down to 8 percent in Q3 of 2017-18 with a rise of 14 percent during demonetisation period. Surprisingly, the credit growth was to the tune of 16 percent during 2012-13 but came down to around 6 percent in 2017-18. Notably the credit growth has slowed down post- demonetisation except in Q4 of 2016-17, just immediately after the demonetisation period. The interest rates measured through bank rate, call money rates and treasury bills have hovered around 8 percent during 2012-13, remained stable well above 7 percent till 2016-17 and came down to 6 percent in 201718. The behaviour of interest rate coincides with the flow of money supply as there was much growth in broad money during 2012-13, but it slowed down thereafter. This phenomenon indicates that high growth in money supply might have created inflationary pressures. In this sense the argument of demonetisation to curb the asset bubbles seems partly justified. The credit-deposit ratio (measured on right hand side in Figure 1) has remained stable in past couple of years. Similar behaviour is noticed for investment-deposit ratio as well. It can be argued that stable credit deposit ratio with rising deposit base implied that absolute credit increased. But in terms of growth in credit, it is observed that the current credit growth is much lower than its previous levels. The increase in credit may be limited due to growing Non-Performing Assets (NPAs) in the banking sector and also amid the growing capital requirements under Basel accord. With these two factors banks are safeguarding their positions, while limiting the credit expansion. Herein, the argument that demonetisation move would help in investment growth due to falling interest rates with surplus liquidity, is not evidenced strongly.

Figure 3 presents the average turnover behaviour for select financial markets. It is observed that the call money and treasury bills market experienced a marginal dip during demonetisation but these markets regained their levels of the previous years. Collateralized Borrowing and Lending Obligation (CBLO) market and repo market noticed an upward movement during December 2016 but again came back to their original levels, moving in a stable manner thereafter. This implies that the short term financial market is unaffected from the demonetisation move. As such Indian financial markets have not exhibited drastic volatile behaviour.

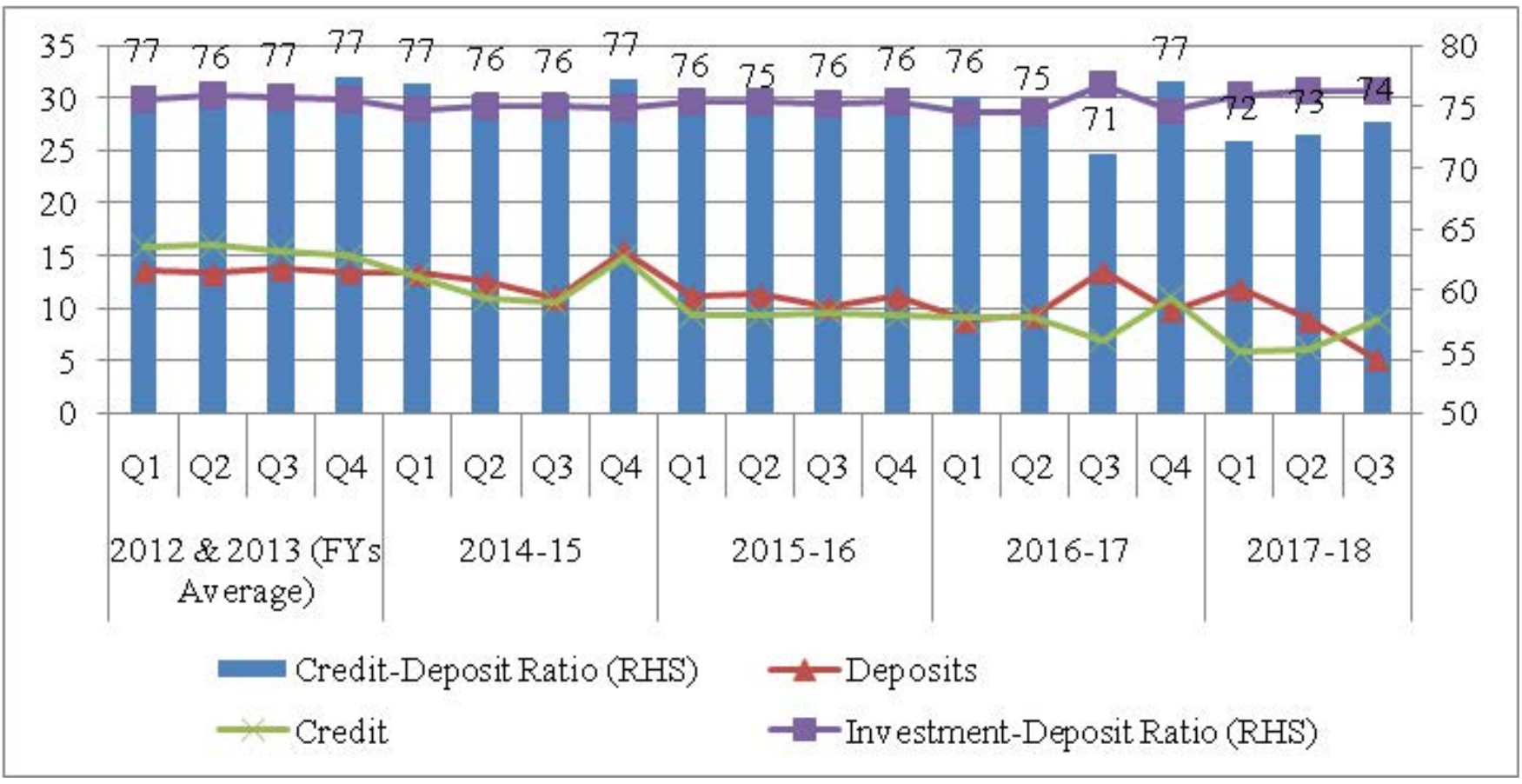

Source: Authors' Compilation from Monthly Bulletin of RBI

Figure 1. Growth Rate of Banking Indicators (Percent) 


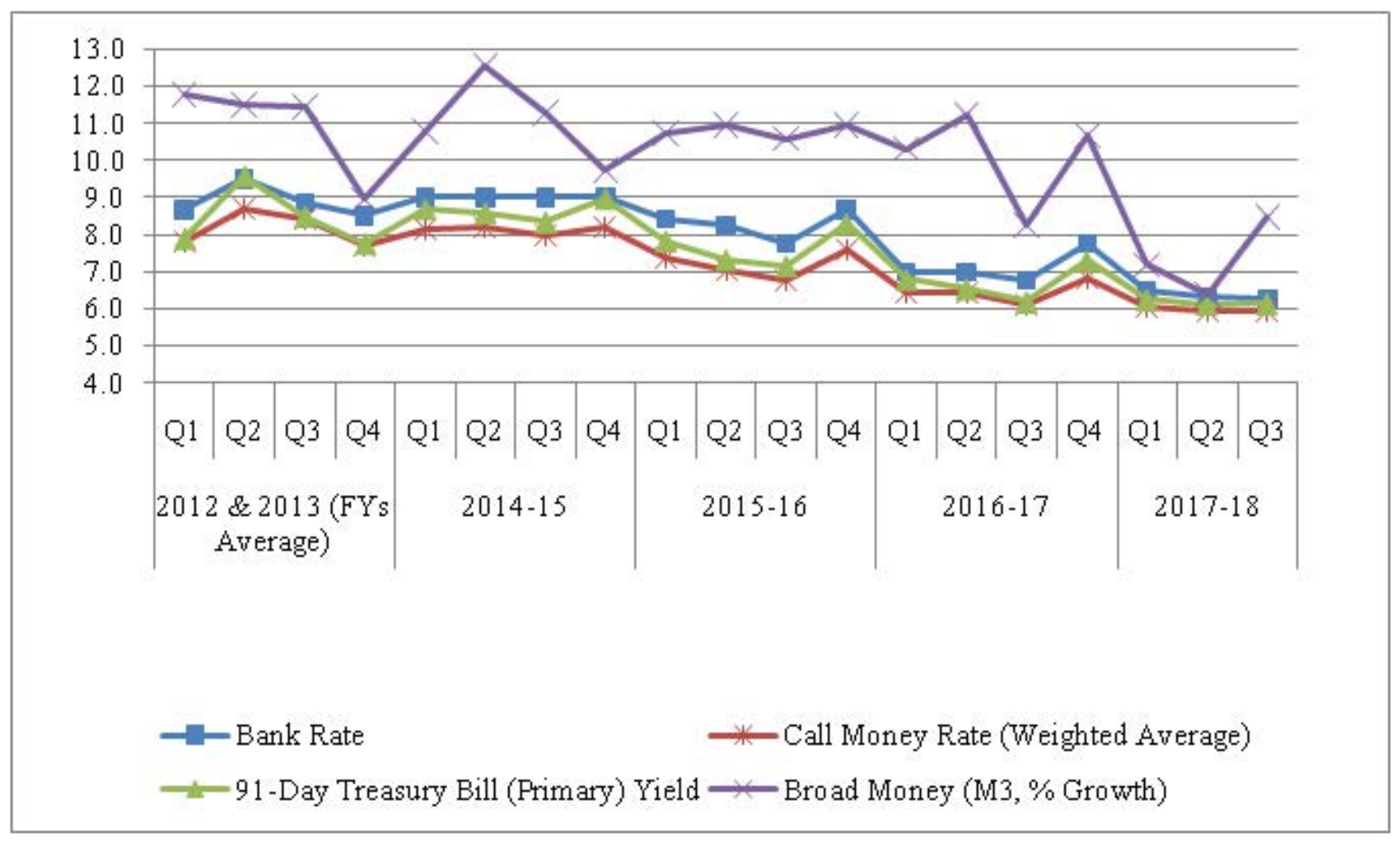

Source: Authors' Compilation from Monthly Bulletin of RBI

Figure 2. Interest Rates and Money Supply
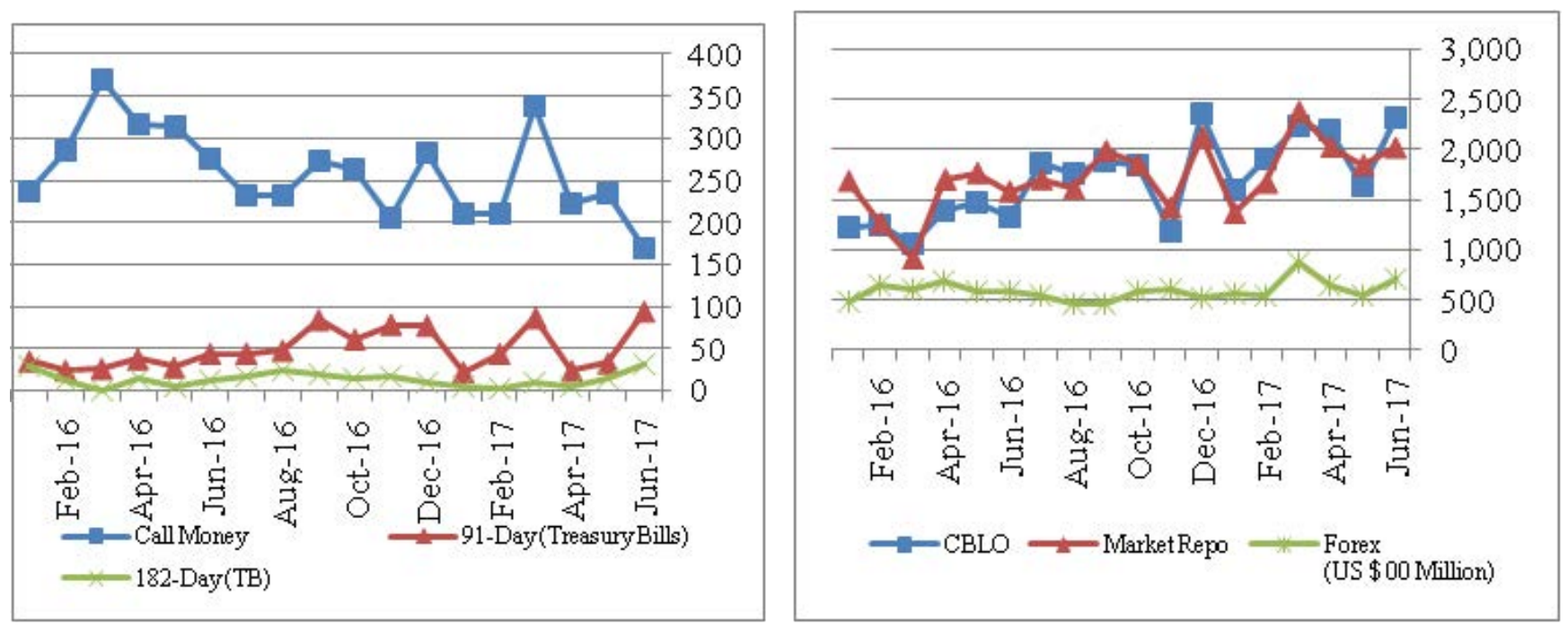

Source: Authors' Compilation from Monthly Bulletin of RBI

Figure 3. Turnover in Select Financial Markets (Rs. Billion) 
Prior to demonetisation, the Indian public held cash equal to 62 percent of India's M1 money supply as compared to less than 0.1 percent in the United States. This phenomenon reflects the intention of the Government to reduce the public cash ratio through demonetisation. The ratio of public currency to narrow money (M1) had declined to 40 percent by the end of December, 2016, after that the ratio increased but still the value was much lower in the month of May, 2017 as compared to its previous peak level of more than 60 percent during mid 2016 (RBI, Monthly Bulletin, various issues $)^{17}$. It can be inferred that demonetisation has helped in reducing the cash in hands and improved the deposits base which may be fruitful for the banking sector to maintain capital requirements amid the new accord of Basel III ${ }^{\mathrm{k}}$.

\subsection{Demonetisation and Economic Growth}

Figure 4 presents the year-on-year growth rates for various quarters in gross domestic product. In order to assess the impact of demonetisation, the fourth quarter values of different years are compared. Growth rate was 9 percent in Q4 of 2015-16 and came down to 6 percent in Q4 of 2016-17 and growth has remained stable at 6 percent thereafter. In terms of aggregate growth, it can be argued that the demonetisation move has slowed down growth pace of the economy. The adverse impact of demonetisation move is apparent for the industrial sector with its growth coming down to zero percent in Q1 of 2017-18 which generally had been about 10 percent in Q1 for each of the past three years (2014-17). Services sector has remained unaffected and reported stable growth. The investment growth measured through gross fixed capital formation was about 10 percent during Q1 of 2016-17, a period before the demonetisation move, but came down to negative in Q4 of the same financial year and about 2 percent in Q1 of 2017-18. However, investment growth revived during Q2 and Q3 of the current fiscal year. Interestingly consumption expenditure growth has remained stable in the past couple of years even during demonetisation period. The stable demand growth is the driving factor for the Indian economy, which has been able to absorb the adverse impact of such economic shocks.

\subsection{Demonetisation and Real Economy}

Figure 5 presents the behaviour of the Index of Industrial Production (IIP) at the aggregate level as well as based on sectors and use-based classification. The index of industrial production is the demand side indicator in the economy. In terms of year-on-year growth in IIP in aggregate, the Q1 growth for year 2017-18, a period immediately succeeding demonetisation noticed a significant fall and revival thereafter. In fact, a fall in the growth of IIP in Q1 was witnessed in the year 2012-13 and 2015-16 as well. Specifically, the fall in growth of IIP in Q1 in 2017-18 is attributed to demonetisation. However, the index recovered to its previous level immediately. The impact of demonetisation was mainly offset by upsurge in consumer non-durable goods. However, durable goods saw a significant dip in the post-demonetisation period.

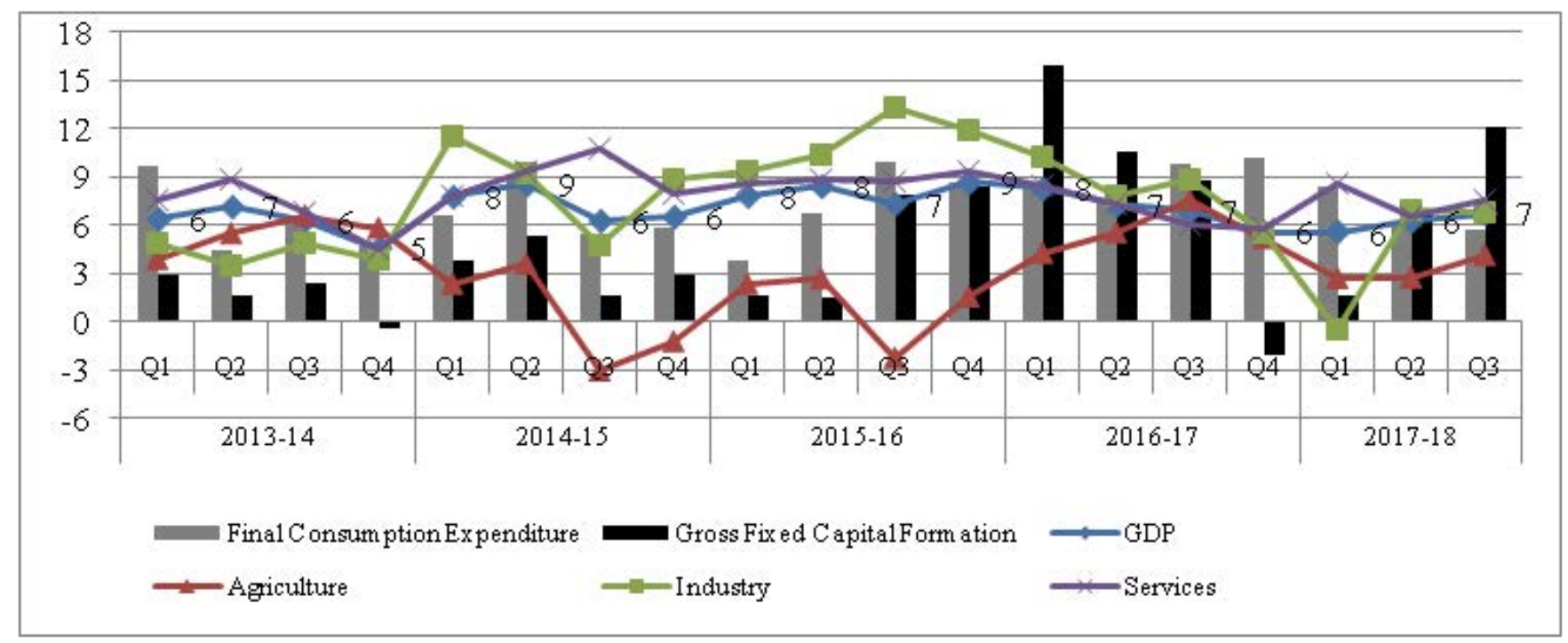

Source: Authors' Compilation from Monthly Bulletin of RBI

Figure 4. Growth Rates (Percent) of GDP and its Components 
In terms of use based classification, primary goods index remained stagnant with minor fluctuations. In terms of impact on productive capacities, it is observed that IIP for capital goods saw a significant dip in Q2 of 2016-17, a quarter before the demonetisation move. With marginal rise in Q4 of the demonetisation year, the index again fell down in Q1 of 2017-18, but reported significant growth in Q2 (second half) of 2017-18. Notably, the capital goods index has reported higher growth after demonetisation compared to its average level of 2013-15. Indices for intermediate goods and infrastructure goods noticed a dip in the following quarters of the move but regained to their previous levels in Q3 of 2017-18. The infrastructure sector experienced a downfall in year 2015-16 which can be attributed to more stringent laws for real estate. Over the past couple of years, the general IIP has remained stable however the mining sector has reported volatile behaviour primarily due to the stringent enforcement of regulatory mechanism.

In sum, it can be argued that the impact of demonetisation was noticed in the initial quarters post the move, but the economy moved to its previous level quite
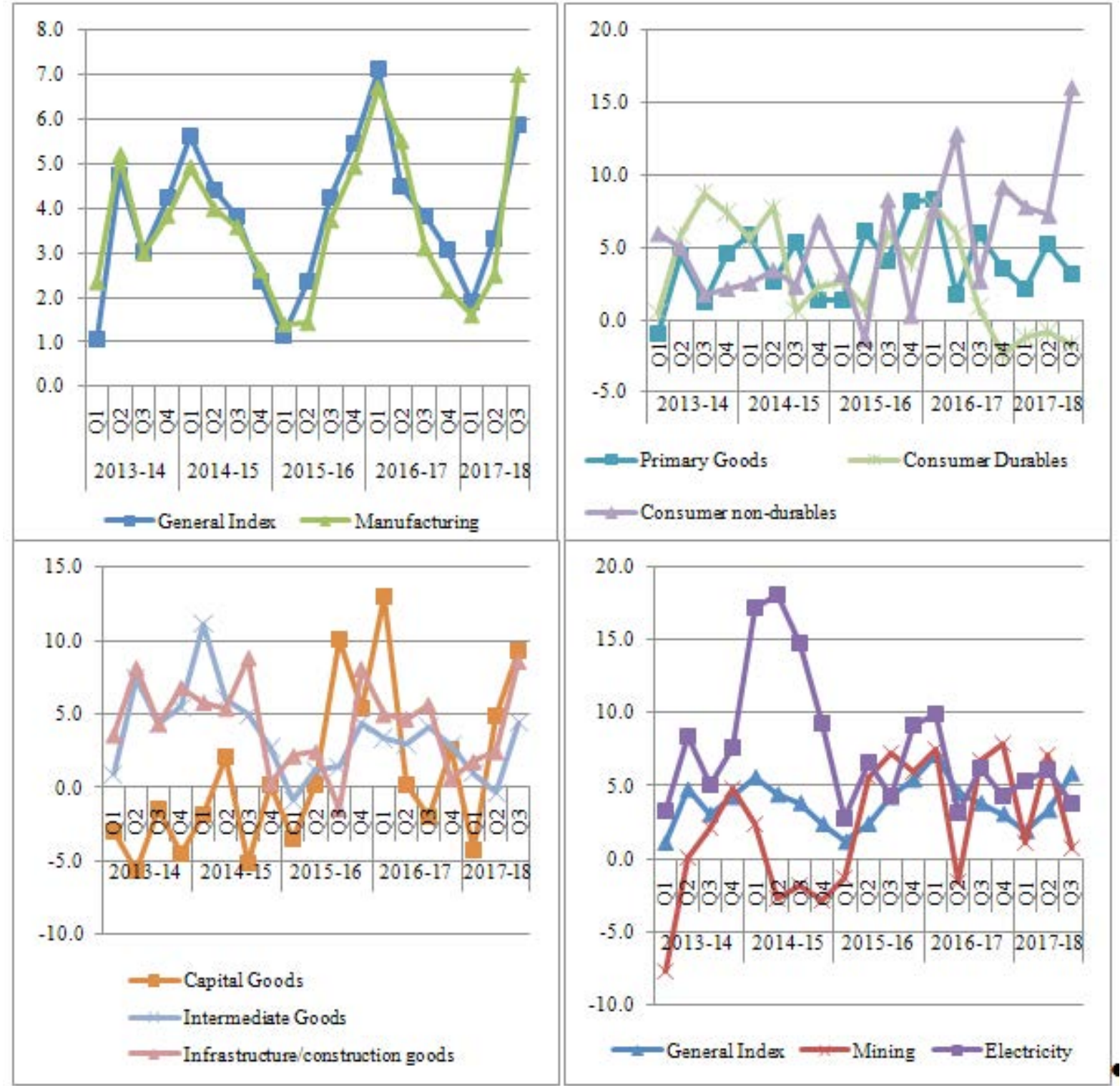

Source: Authors' Compilation from Monthly Bulletin of RBI

Figure 5. Behaviour of Real Economy- Index of Industrial Production 
quickly. The quick revival of the Indian economy is similar with the phenomenon of the Global Financial Crisis of 2008-09, when the Indian economy showed resilience and remained quite isolated from the setbacks of the financial crisis worldwide. This reflects that the economy has huge potential from the demand side, to keep the economy safe from any financial shock. The key concern for the Indian economy is to revive its previous growth levels of investment to attain a high growth trajectory.

\subsection{Demonetisation and Inflation}

The growth rate in consumer price index (year over year) for aggregate level is presented in Figure 6. It is evident that inflation measured through Consumer Price Index (CPI) and CPI for Industrial Workers (CPI-IW) has remained around 10 percent during the 2012-13 and reached around 4 percent in the Q3 of 2017-18. The figure clearly shows that inflation level has eased after the demonetisation move. The inflation scenario coincides with the trend in money supply, as slowdown in money growth has eased the inflation, partly. Based on these statistics, it can be inferred that higher money supply might have created asset bubbles and demonetisation along with other monetary policy measures, have helped curb these bubbles. The year-on-year comparison states that WPI showed negative growth during 2015-16 and reported positive growth after the demonetisation move.

\subsection{Demonetisation and Government Balances}

The impact of demonetisation on the Union Government accounts is mainly perceived on the tax revenue collection. Figure 7 presents the values of different components of government accounts. The blue bars of the first part of Figure 7 shows that tax collection was Rs 24 billion in Q4 of 2015-16 and the same has increased to Rs 28 billion in Q4 of 2017-18 (next quarter to the demonetisation move). One observation can be made that the tax revenue in absolute terms over corresponding quarters of every year is rising. This outcome is obvious as the economy is expanding its base over a period of time. The revenue expenditure has also exhibits the tendency of gradual rise over different quarters. In sum, if we see the growth pattern, the tax revenue has improved which favors the positive impact of demonetisation. But measured in ratio terms, the tax revenue receipts have not increased considerably and hence, demonetisation does not seem to have had much impact.

\subsection{Demonetisation and External Sector}

Figure 8 presents the trend analysis for Indian exports and imports over the past five years. It is observed that growth

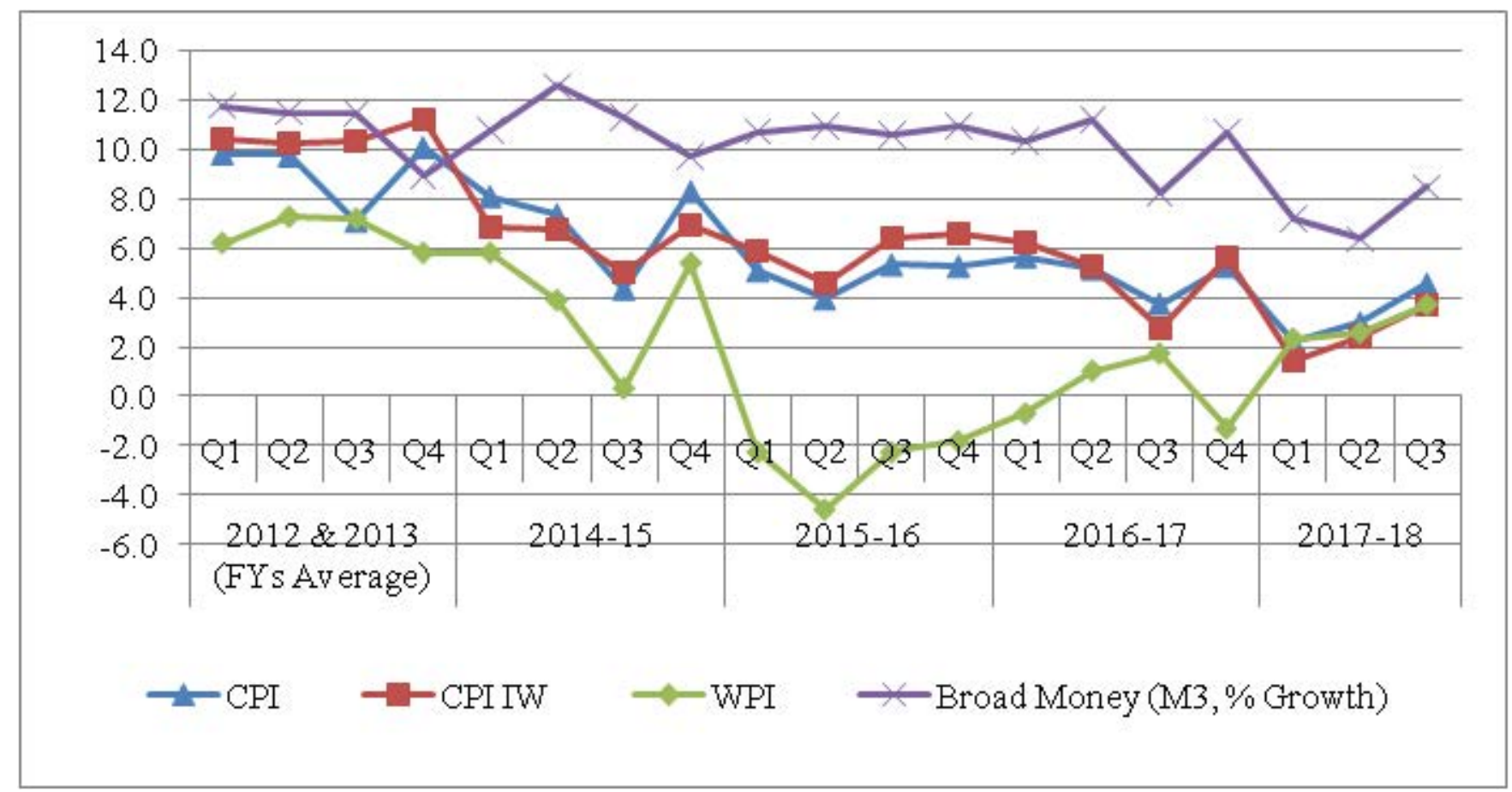

Source: Authors' Compilation from Monthly Bulletin of RBI

Figure 6. Inflation Behaviour in India (Aggregate Commodities) 
rate of imports has been higher than the exports growth in Q2 of 2014-15. For year 2015-16, the exports as well as imports growth rates have appeared negative, however shown positive growth during the period of demonetisation. In the quarter following demonetisation, the growth has fell down drastically but later revived and stood well above 10 percent in the first three quarters of 2017-18. These statistics indicate that demonetisation did not have much adverse impact on India's trade performance.

\subsection{Demonetisation, Rural and Informal Economy}

The impact of demonetisation was also seen in the rural and informal economy. As per the report of India Ratings and Research (Ind-Ra), borrowers were unable to meet their dues as earning members lost on average, one to three- months wages or income due to demonetisation in FY2017. In an estimate Fitch Group Company, indicated that aggregate collection efficiency of majority of Micro Financing Institutions stood at 75-80 percent in May 2017 compared with a low of 50 to 60 percent in December $2016^{18}$. Two- Wheeler sales, an indicator of largely rural demand for vehicles, registered a growth at 9.24 percent in April-July 2017 over April-July 2016 ${ }^{19}$. According to data available with the Society of Indian Automobile Manufacturers (SIAM), passenger vehicle sales increased 7.8 percent to 2.75 lakhs units in February 2018. While sales of commercial vehicles went up by 31 percent to 87777 units and those of twowheelers grew by 23.8 percent to 16.86 lakhs units ${ }^{20}$. These statistics indicate that demonetisation has adversely affected the informal sector temporarily.

Further, Medium and Small Micro Enterprises (MSME) workers and labourers who were retrenched from their jobs during demonetisation (November and December, 2016), but reemployed later ${ }^{21}$. The same is evidenced with recent unemployment statistics provided by Centre for Monitoring Indian Economy (CMIE) and Bombay Stock Exchange (BSE). The unemployment rate inched marginally during demonetisation period but came down thereafter (Figure 9). However, there is a marginal increase in unemployment rate since mid-2017 in India and that may be attributed to slowdown in the industrial pace amid indirect tax reform of GST.

\subsection{Demonetisation, Formal Economy and Digital Economy}

This section attempts to understand whether demonetisation has pushed India towards a more formal and digital

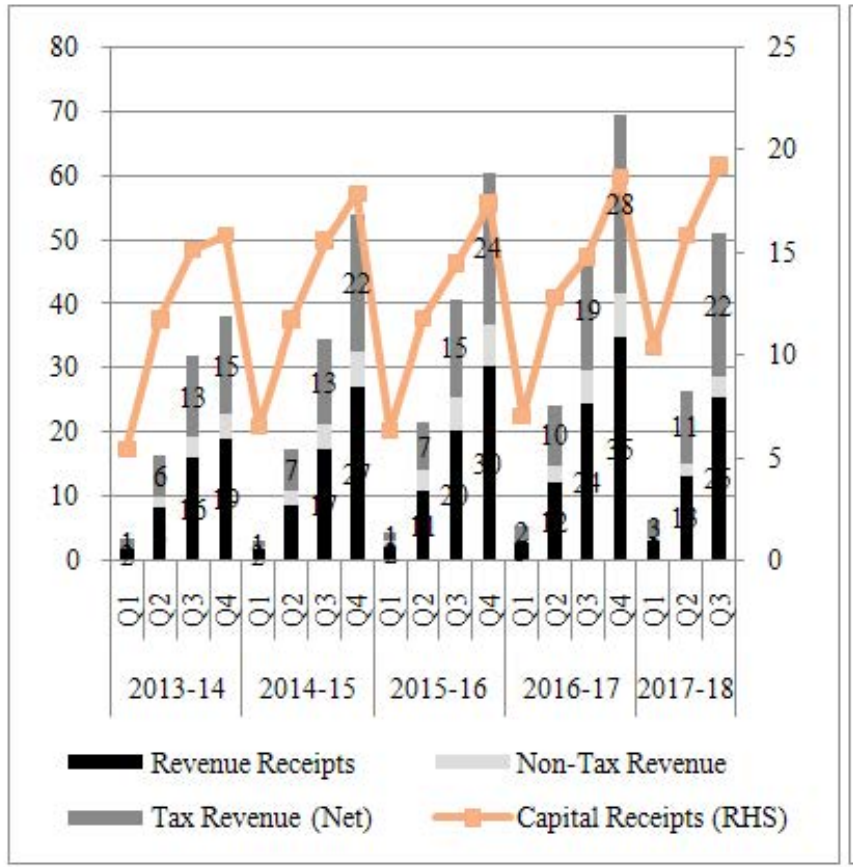

Source: Authors' Compilation from Monthly Bulletin of RBI

Figure 7. Union Government Accounts (Rs Billion)

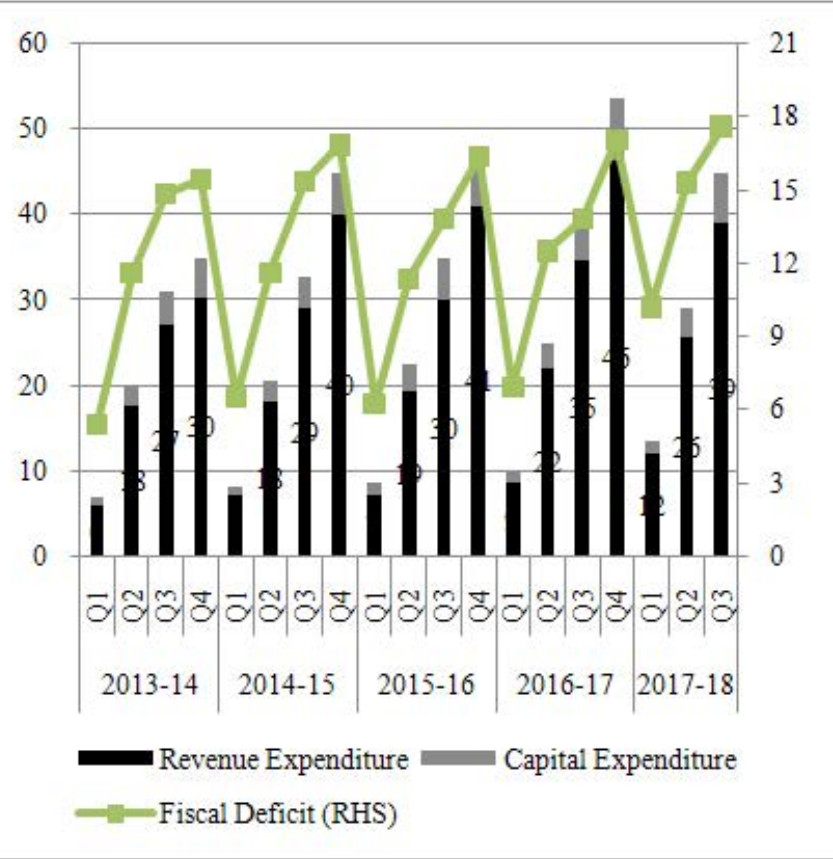




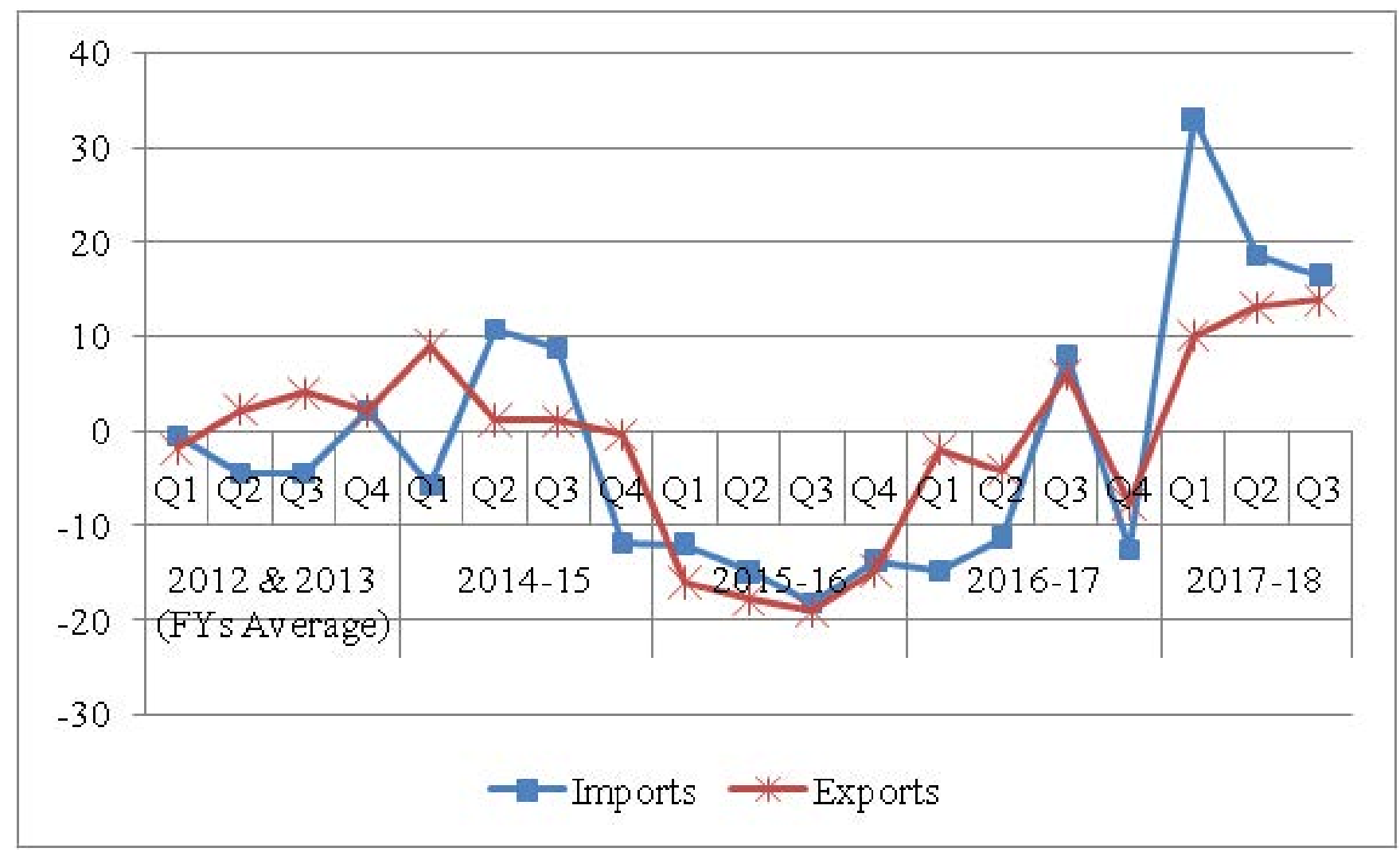

Source: Authors' Compilation from Monthly Bulletin of RBI

Figure 8. Exports and Imports Growth Rates (Percent)

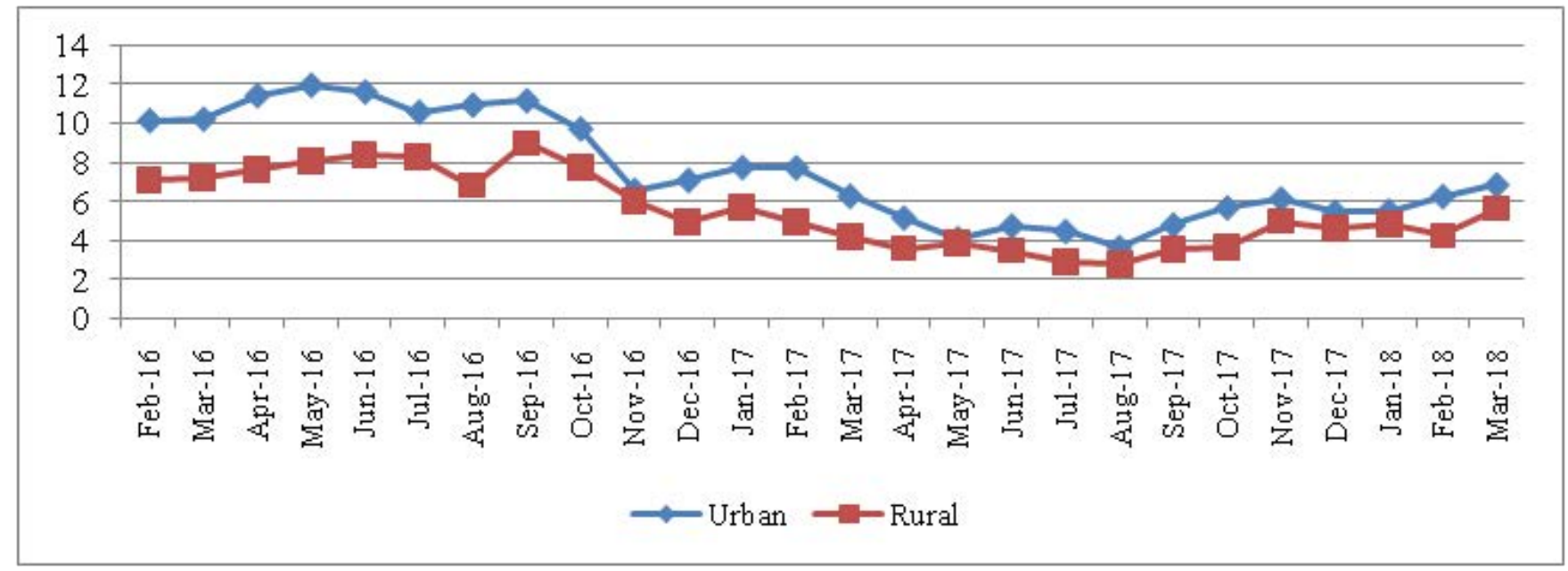

Source: BSE, CMIE India

Figure 9. Unemployment Rate (Percent) - 30 Days Moving Average 


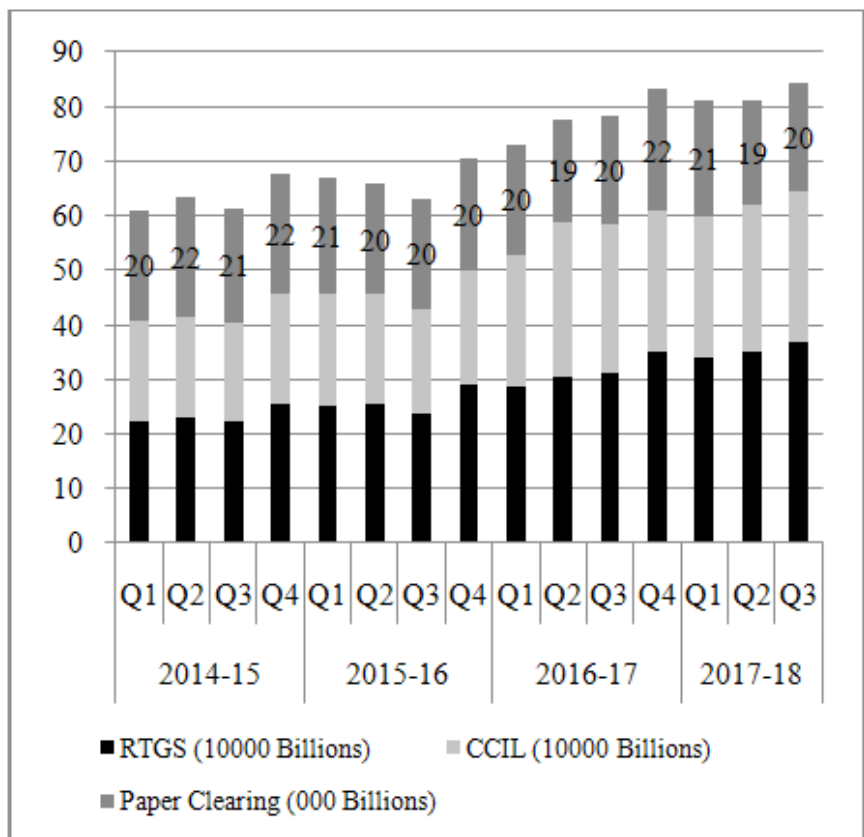

Source: Authors' Compilation from Monthly Bulletin of RBI (Various Issues) Figure 10. Digital Transactions: Usage of Cards, Mobile Banking

economy. Has it been effective in countering fake currency and black economy? From Figure 10, it is evident that digital transactions gained momentum in the quarter immediately following demonetisation and then stabilized. Even the volume of paper clearing in the post-demonetisation period remained the same as their levels in 2014-16. The impact of demonetisation was apparent in the volume of card payments which slowed down in Q3 of 2016-17, quite obviously amid the withdrawal limit, but thereafter card payments turnover increased voluminously. Even during demonetisation there was a large increase in mobile banking which slowed after the first quarter of 2017-18. The numbers of Point of Sale (PoS) machines have also increased significantly. The launch of goods and services tax could be a primary factor for the same. It can be concluded that demonetisation appears to have resulted in increase in digital transactions, which however, could not be sustained.

\section{Conclusion}

The enormous move of demonetisation has invited much attention of policy practitioners on both grounds- positive as well as negative. The descriptive analysis carried out in the study highlights a mixed response about the impact

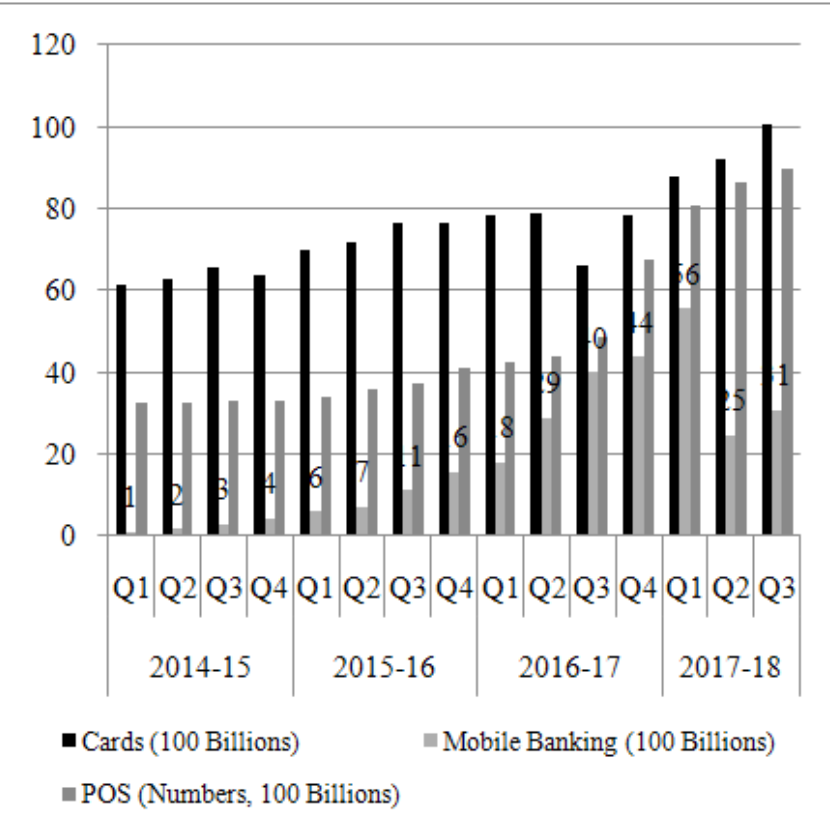

assessment. It can be inferred that demonetisation has helped the banks in improving the deposits base. However, credit growth has been much lower in the past year as compared to the previous level. The rationality behind this behavior is that banks are safeguarding themselves with risk of non-performing assets and growing capital requirements. Herein, the argument that demonetisation move would supplement the investment base with falling interest rates is not evidenced strongly. Demonetisation has slowed down the growth pace of economy and adversely affected the industrial sector, with growth coming down to its lowest levels in Q1 of 2017-18. The investment growth measured through gross fixed capital formation was about 10 percent during Q1 of 2016-17, before demonetisation, but became negative in Q4 of the same financial year before rising to about 2 percent in Q1 of 2017-18. The positive note for the economy is that consumption expenditure growth has remained stable in recent years including the demonetisation period. Considering Government accounts, tax revenue growth has improved which favors the positive impact of demonetisation. However, tax revenue receipts have not increased considerably. In terms of trade performance, both the trade components exhibited a downturn in 
the quarter succeeding demonetisation, but thereafter reported significant positive growth. Unemployment rate inched up marginally during the demonetisation period but came down thereafter and ended with a marginal increase in unemployment rate from mid-2017 which could be attributed to slowdown in the industrial pace amid indirect tax reform of GST. The rural economy, as proxied from the vehicles growth, has indicated a positive note for the informal sector. The impact of demonetisation was visible in the increase in volume of card payments with mobile banking as well as the card payments turnover increasing voluminously post- demonetisation. The numbers of PoS machines have also increased largely on account of launch of goods and services tax.

In sum, it can be argued that the impact of demonetisation was noticed in the initial quarters following the move, however, the economy moved back to previous levels very quickly reflecting its robustness. This was akin to the resistance capacity exhibited by the Indian economy during global financial crisis. A stable demand growth has been the driving factor for the Indian economy, enabling it to absorb the adverse impacts of such economic shocks. The slowdown in the investment growth is a key concern for India which needs to be revived to help the economy move on a higher growth trajectory.

\section{References}

1. Lahiri AK. Demonetisation and the Cash Shortage, NIPFP WP No. 184; 2016 Dec.

2. Kohli and Kumar. Economic rationale of 'Demonetisation'. Economic and Political Weekly. 2016 Dec; 51(53):31.

3. Bhalla SS. Black Cash in India, The Indian Express; 2016 Dec 06.

4. Sahoo P, Ashwani. Here's what the impact will be of Rs 500, Rs 1,000 note ban: A massive change in informal cash-carry system to formal financing, Financial Express; 2016 Nov 10.

5. Gurumurthy. S De-mon - a multidimensional project, Indian Express; 2017 Sep 05.

6. CII. Money Market after Demonetisation, Communiqué, Confederation of Indian Industry. 2017 Jan.

7. Bryson JH, Pershing HE. Economic Analys, Indian GDP Growth Depressed by Demonetisation, Special Commentary, Economics Group. This report is available on wellsfargo.com/economics and on Bloomberg WFRE; 2017 Feb 28.

8. Chand R, Singh J. Member and Consultant, respectively, NITI Aayog, Agricultural Growth in the Aftermath of Demonetisation.
9. Reserve Bank of India. Macroeconomic Impact of Demonetisation - A Preliminary Assessment; 2017 Mar 10.

10. Sabnavis M, Ranadive R, Mishra M. Four months after demonetisation: Where do we stand?, CARE Ratings; 2017 Mar 15.

11. Drèze J. Demonetisation Decimates Ranchi's Economy, The Wire, 26 December 2016; 2016 Dec 26.

12. Sibal P. In Amritsar, Decline in Earnings Doesn't Translate to Anti-Demonetisation Sentiments; 2017 Jan 16.

13. Anil V. In Four Areas in Delhi, Average Income Has Declined by $60 \%$ After Demonetisation. 2017 Jan 07.

14. Bhattacharya K, Mitra S, Pal S, Saha B. Reviving the informal sector from the throes of demonetisation. [Internet]. 2017. Available from: Retrieved from http://eprints.lse.ac.uk.

15. Waknis P. Demonetisation: Some Theoretical Perspectives. Jan 23 2017. Retrieved from MPRA: https://mpra.ub.unimuenchen.de/id/eprint/76391.

16. Narain and Rani A. The stability of Indian stock market after demonetisation. Business Analyst, 2017 Mar; 37(2):39-56.

17. RBI. Monthly Bulletin Various Issues, Reserve Bank of India. March 102018.

18. Moneylife Digital Team (June 15,2017). Demonetisation could cause capital erosion for MFIs, NBFCs and SFBs in FY2018.

19. SIAM. Automobile wholesale picks-ups for stock replenishment, Press Release; 2017 Aug 11.

20. Mukherjee S. Passenger vehicle sales up $7.8 \%$ in February, Economic Times; 2018 Mar 12.

21. Bhagat J. New plans to boost self-employment: Shri Kalraj Mishra, PCQUEST; 2017 Jul 06.

\section{Notes:}

${ }^{\text {a }}$ India Tax/GDP is $16.7 \%$.

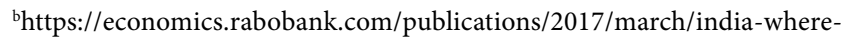
is-the-negative-impact-of-demonetization/

chttps://www.adamsmith.org/blog/the-very-real-impact-of-indiasdemonetization

${ }^{\mathrm{d}}$ Demonetisation has raised the individual tax base by 20 percent, advance tax collections for 2017-18 by 42 percent and self-assessment tax (paid now for last year) by 34 percent.

${ }^{\mathrm{e}}$ Notable the RBI has spent Rs 3,420 crores in 2015-16 for printing money thereby resulting into additional cost of Rs. 4545 crores for printing new currency.

${ }^{\mathrm{f}}$ In just 18 months between April 2015 and September 2016, the stock of Rs $500 / 1000$ notes rose by Rs 4.8 lakh crores.

${ }^{\mathrm{g}}$ Asset prices in India rose by ten times during 2004-10 as compared to the earlier five years (1999-2004).

${ }^{\mathrm{h}}$ Demonetisation Module 13.1 Contemporary Themes in India's Economic Development and the Economic Survey

${ }^{i}$ Premiums collected by Life Insurance Corporation of India (LIC) increased by more than 140 percent (y-o-y) in November 2016 as compared with less than 50 percent by private sector life insurance companies. 
${ }^{j}$ Report titled : Impact of demonetization on GDP growth in FY17, dated 18th November.
${ }^{\mathrm{k}}$ Basel III aims to strengthen global capital and liquidity regulations with the goal of promoting a more resilient banking sector and to improve the banking sector's ability to absorb shocks arising from financial and economic stress. 